\title{
Amyloid proteins of plants and microorganisms: biological functions and participation in the formation of supra-organismal systems \\ Nizhnikov A.A.
}

All-Russia Research Institute of Agricultural Microbiology, St. Petersburg, Russia; St. Petersburg State University, St. Petersburg, Russia

E-mail: a.nizhnikov@arriam.ru

Key message. Here we will review the latest advances in the study of functional amyloids of plants and symbiotic bacteria demonstrating the involvement of these protein fibrils in protein storage in plant seeds and formation of supra-organismal interactions.

Keywords: Amyloid, protein fibril, root nodule bacteria, seeds, symbiosis

Amyloids are protein fibrils that have a special spatial structure called "cross- $\beta$ ". These protein aggregates are associated with the development of more than 40 predominantly incurable human diseases, among which there are those of very high social importance, such as Alzheimer's disease. Amyloids may be only pathological but also functional. Such functional amyloids are found in archaea, bacteria (mainly pathogenic), and eukaryotes. For example, in humans, they are involved in the polymerization of melanin and tooth enamel, the regulation of antiviral response, hormone storage, and other cellular functions. Plants and symbiotic bacteria remained the most significant groups for humans in which amyloids were not found. Our studies revealed amyloids formed in plants in vivo. In particular, seed storage proteins were found to form amyloids that are resistant to treatment with proteases of the gastrointestinal tract and toxic to eukaryotic cells [1]. We also performed a screening of amyloid proteins in symbiotic root nodule bacteria resulted in the identification of two novel amyloids formed in vivo by proteins of the bacterial outer cell membrane involved in the development of the initial stages of plant-microbial symbiosis [2]. It is noteworthy that the amyloids of both plants and root nodule bacteria are formed by proteins with a similar structure called the " $\beta$-barrel".

The research was carried out with the support of the Russian Science Foundation grant 17-16-01100.

\section{Амилоидные белки растений и микроорганизмов: биологические функции и участие в формировании надорганизменных систем}

Нижников А.A.

Всероссийский научно-исследовательский институт сельскохозяйственной микробиологии, Санкт-Петербург, Россия; Санкт-Петербургский государственный университет, Санкт-Петербург, Россия

\begin{abstract}
Аннотация. В докладе будут рассмотрены последние достижения в области исследования функциональных амилоидных белков растений и симбиотических бактерий, демонстрирующие вовлеченность этих амилоидных фибрилл в запасание белка семян и надорганизменные взаимодействия.
\end{abstract}

Ключевые слова: Амилоид, белковая фибрилла, клубеньковые бактерии, семена, симбиоз

Амилоидами называют белковые фибриллы, обладающие особой пространственной структурой, называемой «кросс$\beta »$. Эти белковые агрегаты ассоциированы с развитием более 40 преимущественно неизлечимых заболеваний человека, среди которых есть обладающие весьма высокой социальной значимостью, такие как болезнь Альцгеймера. Амилоиды бывают не только патологическими, но и функциональными. Такие функциональные амилоиды обнаружены у архей, бактерий (преимущественно патогенных), эукариот. Например, у человека они вовлечены в полимеризацию меланина и зубной эмали, регуляцию антивирусного ответа, запасание гормонов и выполнение других клеточных функций. Наиболее значимыми для человека группами, у которых не были обнаружены амилоиды, оставались растения и симбиотические бактерии. Проведенные нами исследования позволили впервые идентифицировать амилоиды, образующиеся у растений in vivo. Оказалось, что амилоиды образуют запасные белки семян, причем эти амилоиды облают устойчивостью к протеазам желудочно-кишечного тракта и токсичностью для клеток эукариот [1]. Также мы провели системный скрининг амилоидных белков у симбиотических клубеньковых бактерий, в результате которого нам удалось идентифицировать два новых амилоида, образуемых in vivo белками наружной клеточной мембраны, вовлеченными в формирование начальных стадий растительно-микробного симбиоза. Примечательно, что идентифицированные нами амилоиды как растений, так и клубеньковых бактерий образуются белками со сходной структурой, называемой «

Исследования выполнены при поддержке гранта Российского научного фонда 17-16-01100.

[1] Antonets K.S., Belousov M.V., Sulatskaya A.I., Belousova M.E., Kosolapova A.O., Sulatsky M.I., Andreeva E.A., Zykin P.A., Malovichko Y.V., Shtark O.Y., Lykholay A.N., Volkov K.V., Kuznetsova I.M., Turoverov K.K., Kochetkova E.Y., Bobylev A.G., Usachev K.S., Demidov O.N., Tikhonovich I.A., Nizhnikov A.A. Accumulation of storage proteins in plant seeds is mediated by amyloid formation // PLOS Biology, 2020, V.18(7), e3000564.

[2] Kosolapova A.O., Belousov M.V., Sulatskaya A.I., Belousova M.E., Sulatsky M.I., Antonets K.S., Volkov K.V., Lykholay A.N., Shtark O.Y., Vasilieva E.N., Zhukov V.A., Ivanova A.N., Zykin P.A., Kuznetsova I.M., Turoverov K.K., Tikhonovich I.A., Nizhnikov A.A. Two novel amyloid proteins, RopA and RopB, from the root nodule bacterium Rhizobium leguminosarum // Biomolecules, 2019, V.9, e694. 